Original Article

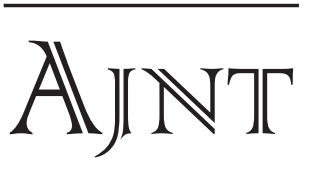

\title{
Technetium-99m Sestamibi Scintigraphy Pattern in Patients with Secondary Hyperparathyroidism
}

\author{
Ahmed A Kandeel ${ }^{a^{*}}$, Mohamed A Hawary ${ }^{\mathrm{b}}$ and Hisham S Ebaid ${ }^{\mathrm{c}}$ \\ a Oncology and Nuclear Medicine Department (NEMROCK), Kasr El-Ini Hospital, Cairo University, Egypt \\ b Radiology Department, Fayoum University, Egypt \\ c Dialysis Department, Al-Agouza hospital, Giza, Egypt
}

\begin{abstract}
Introduction: Metabolic bone disease is one of the major complications of end stage renal disease (ESRD). We aimed in this investigation to explore the role of Technetium$99 \mathrm{~m}$ sestamibi ${ }^{99 \mathrm{~m}} \mathrm{Tc}$ MIBI) scintigraphy in the preoperative assessment of refractory hyperparathyroidism in hemodialysis (HD) patients.
\end{abstract}

Methods: Dual-phase ${ }^{99 \mathrm{~m}} \mathrm{Tc}$ MIBI parathyroid scintigraphy was performed for 23 patients with ESRD who have persistent intact parathyroid hormone (iPTH) levels exceeding $300 \mathrm{pg} / \mathrm{ml}$. Based on scintigraphy results, 13 patients underwent neck exploration during which only glands with positive scintigraphy findings were removed.

Results: Among the six patients who had iPTH levels $<800 \mathrm{pg} / \mathrm{ml}$, only one patient had positive scintigraphy findings $(16.7 \%)$. Among the 17 patients who had iPTH levels $\geq 800 \mathrm{pg} / \mathrm{ml}, 16$ patients had positive scintigraphy findings $(94.1 \%)$. ${ }^{99 m} \mathrm{Tc}$ MIBI scan detected 23 positive sites of focal trace uptake in those 17 patients. Partial parathyroidectomy was performed for 13 patients, removing in total 19 glands, while four patients declined surgery. On histological examination, 12 glands showed diffuse hyperplasia, four glands showed nodular hyperplasia and three glands revealed parathyroid adenoma. The three glands with parathyroid adenoma were correctly identified prior to surgery by ${ }^{99 \mathrm{~m}} \mathrm{Tc}$ MIBI scintigraphy. The long-term outcomes of these patients are now being monitored.

Conclusion: ESRD patients with iPTH level $\geq 800$ pg/ $\mathrm{ml}$ are more likely to have positive sites of focal tracer uptake on MIBI scan than patients with lower iPTH levels. Dual-phase ${ }^{99 \mathrm{~m}} \mathrm{Tc}$ MIBI scintigraphy has the ability to correctly identify parathyroid adenoma prior to surgical exploration in these patients.

* Corresponding author; Cairo University, Oncology \& Nuclear medicine (NEMROCK), No.1424, 7th area, 4th discrete, 6th October, 11461, Egypt; E mail: ahmedkandeel@yahoo.com
Keywords: Hyperparathyroidism, parathyroid adenoma, parathyroid hyperplasia, scintigraphy, ${ }^{99 \mathrm{~m} T c}$ sestamibi

\section{Introduction}

Secondary hyperparathyroidism (SHP) is one of the serious complications of end stage renal disease (ESRD) [1]. A number of factors may contribute to SHP, such as hypocalcemia, hyperphosphatemia, vitamin D deficiency and the reduction of vitamin $\mathrm{D}$ and calcium sensing receptors in the parathyroid gland [2]. Through poorly understood mechanisms, these factors lead initially to diffuse and polyclonal cell proliferation. Subsequently, in some glands, nodular growth occurs within diffuse hyperplastic tissue. These nodules represent autonomous and monoclonal growth, likely corresponding to the so-called 'tertiary hyperparathyroidism' [3].

Technetium-99m sestamibi ( ${ }^{99 \mathrm{~m} T c}$ MIBI) scintigraphy is now widely used as an alternative method to thallium chloride-201 $\left.{ }^{201} \mathrm{TI}\right) /{ }^{99 m} \mathrm{Tc}$ subtraction scintigraphy which is no longer used in clinical practice for imaging of parathyroid glands $[4,5]$. Dual-phase ${ }^{99 \mathrm{~m}} \mathrm{Tc}$ MIBI scan has demonstrated high specifity, despite low sensitivity, in locating parathyroid glands in patients with secondary hyperparathyroidism [6].

${ }^{99 m}$ Tc MIBI is concentrated within the cells through active transport and passive diffusion, a process facilitated by negative trans-membrane potential found in metabolically hyperactive cells and by the lipophilic nature of ${ }^{99 \mathrm{~m}} \mathrm{Tc}$ MIBI [7]. As increased numbers of mitochondria have been found in hyperactive parathyroid cells, intramitochondrial sequestration may be an additional mechanism of ${ }^{99 \mathrm{~m}} \mathrm{Tc}$ MIBI tissue binding [7]. This may account for slower ${ }^{99 \mathrm{~m}}$ Tc MIBI washout from hyperactive parathyroid compared to normal thyroid and parathyroid tissues [8].

The aim of the present study was to evaluate the role of dual-phase ${ }^{99 \mathrm{~m}} \mathrm{Tc}$ MIBI scintigraphy in the pre-operative 
Table 1: Clinical and biochemical data, scintigraphy findings and histological diagnosis of studied patients

\begin{tabular}{|c|c|c|c|c|c|c|c|c|}
\hline No & $\begin{array}{l}\text { Age } \\
\text { (years) }\end{array}$ & $\begin{array}{l}\text { HD duration } \\
\text { (months) }\end{array}$ & $\begin{array}{l}\text { Phosphorus } \\
\text { (mg/dl) }\end{array}$ & $\begin{array}{l}\text { Calcium } \\
(\mathrm{mg} / \mathrm{dl})\end{array}$ & $\begin{array}{l}\text { iPTH } \\
(\mathrm{pg} / \mathrm{ml})\end{array}$ & $\begin{array}{l}\text { Scintigraphy } \\
\text { result }\end{array}$ & $\begin{array}{l}\text { Site and number } \\
\text { of positive glands }\end{array}$ & $\begin{array}{l}\text { Histological } \\
\text { pattern }\end{array}$ \\
\hline 1 & 52 & 20 & 4.7 & 7.2 & 330 & Negative & - & - \\
\hline 2 & 48 & 45 & 4.4 & 8.5 & 340 & Negative & & \\
\hline 3 & 56 & 50 & 4.3 & 7.8 & 341 & Negative & - & - \\
\hline 4 & 45 & 40 & 4.8 & 8.3 & 535 & Negative & - & - \\
\hline 5 & 30 & 36 & 4.5 & 9.0 & 560 & Negative & - & - \\
\hline 6 & 27 & 108 & 8.2 & 9.5 & 780 & Positive & RL (1) & DHP \\
\hline 7 & 63 & 90 & 4.5 & 7.7 & 890 & Positive & LL (1) & DHP \\
\hline 8 & 65 & 120 & 5.0 & 8.3 & 933 & Negative & - & - \\
\hline 9 & 63 & 108 & 8.2 & 9.5 & 966 & Positive & LL (1) & DHP \\
\hline 10 & 63 & 118 & 8.2 & 9.5 & 1000 & Positive & LL (1) & DHP \\
\hline 11 & 50 & 125 & 4.6 & 7.3 & 1055 & Positive & RL+LL (2) & NHP \\
\hline 12 & 40 & 132 & 4.8 & 7.7 & 1078 & Positive & RL (1) & - \\
\hline 13 & 60 & 90 & 7.4 & 9.1 & 1120 & Positive & RL+LL (2) & NHP \\
\hline 14 & 70 & 120 & 4.8 & 10 & 1200 & Positive & LU (1) & $\mathrm{AD}$ \\
\hline 15 & 63 & 108 & 2.5 & 9.5 & 1200 & Positive & LL (1) & - \\
\hline 16 & 63 & 120 & 4.5 & 9.2 & 1200 & Positive & $\mathrm{RL}+\mathrm{LL}(2)$ & NHP \\
\hline 17 & 50 & 85 & 4.0 & 9.5 & 1215 & Positive & RL+LL (2) & NHP \\
\hline 18 & 63 & 80 & 3.9 & 10.2 & 1500 & Positive & LL (1) & - \\
\hline 19 & 60 & 100 & 2.2 & 10.2 & 1550 & Positive & RL (1) & $\mathrm{AD}$ \\
\hline 20 & 40 & 132 & 3.8 & 9.4 & 1712 & Positive & RL+LL (2) & NHP \\
\hline 21 & 58 & 90 & 4.9 & 9.8 & 1800 & Positive & RL (1) & - \\
\hline 22 & 40 & 180 & 4.8 & 10.3 & 2000 & Positive & RL (1) & $\mathrm{AD}$ \\
\hline 23 & 60 & 96 & 5.5 & 8 & 2161 & Positive & RL+LL (2) & NHP \\
\hline
\end{tabular}

DHP $=$ Diffuse Hyperplasia, NHP = Nodular Hyperplasia, AD = Adenoma, LL $=$ Left Lower, RL $=$ Right Lower, LU $=$ Left Upper

assessment of parathyroid glands of uremic patients with refractory hyperparathyroidism.

\section{Methods}

The study included ESRD patients maintained on regular hemodialysis (HD) who had persistent intact parathyroid hormone (iPTH) levels more than $300 \mathrm{pg} / \mathrm{ml}$ using specific radioimmunoassay. Informed consent was obtained from all patients for a dual-phase ${ }^{99 \mathrm{~m}} \mathrm{Tc}$ MIBI scan. Fifteen $\mathrm{mCi}$ (550 MBq) of ${ }^{99 m}$ Tc MIBI was intravenously injected in all patients. Twenty minutes post-injection, planar anterior imaging of the neck and the upper thorax of supine patients was performed (early phase) using a large field gamma camera with low-energy, high resolution, parallel-hole collimator, $20 \%$ energy window centered at $140 \mathrm{Kev}, 128 \times 128$ matrix for static images and zoom 2.65. The second phase (delayed phase) was performed two hours after the injection of ${ }^{99 \mathrm{~m}} \mathrm{Tc}$ MIBI. Scans were performed on the following day of a dialysis session. All patients had preliminary ${ }^{99 \mathrm{~m}} \mathrm{Tc}$ pertechnetate thyroid scintigraphy performed one week earlier to exclude the presence of thyroid hot nodules or other focal lesions in the thyroid gland. Images were separately scrutinized by two nuclear medicine physicians for foci of abnormally active trace uptake in the expected location of parathyroid glands or other ectopic sites. Patients with positive scintigraphy findings were referred for partial parathyroidectomy, removing only glands identified to have active foci of trace uptake. Unpaired Student's t test was used to compare means and Chi square test was used to compare proportions. $\mathrm{P}$ value $<0.05$ was considered statistically significant.

\section{Results}

The study group included 23 patients with ESRD and refractory hyperparathyroidism. Their mean age was 
Figure 1: Dual phase 99mTc MIBI scan at 20 min (early phase) on the left and at 2 hours (delayed phase) on the right in two patients with uremic hyperparathyroidism: (A) shows right lower parathyroid gland adenoma and (B) shows bilateral lower parathyroid glands hyperplasia

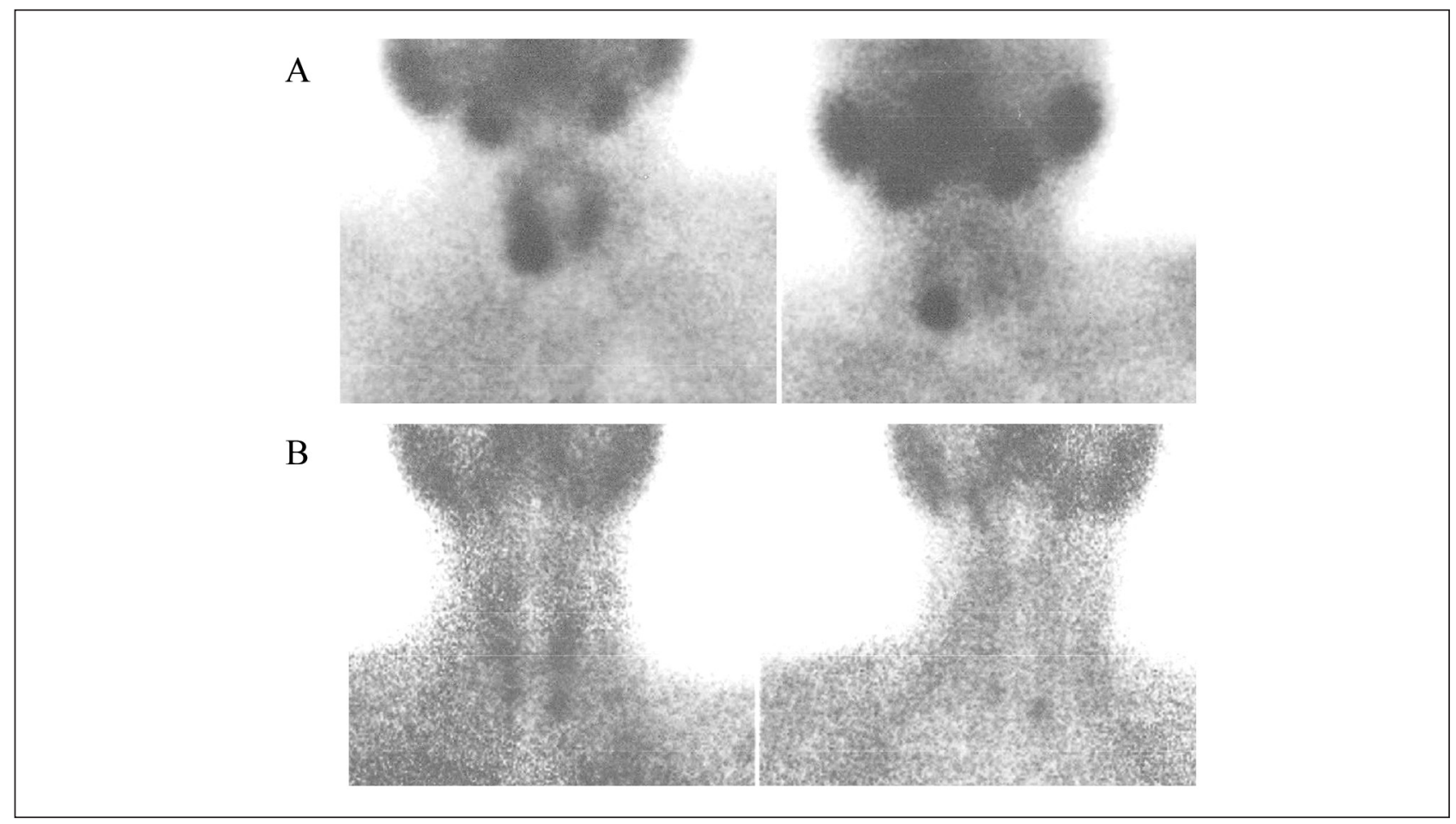

53.4 years (SD 11.7; range 27-70 years). Patients have been on regular HD for a mean duration of 95.3 months (SD 37.4; range 20-180 months). The majority of patients presented with variable symptoms and signs related to metabolic bone disease despite regular treatment with calcium carbonate and calcitriol. This treatment was not interrupted during the course of the present study. The mean pre-dialysis concentration of serum calcium was $8.9 \mathrm{mg} / \mathrm{dl}$ (SD 1; range 7.2-10.3 $\mathrm{mg} / \mathrm{dl}$ ) and the mean pre-dialysis concentration of serum phosphorus was 4.9 $\mathrm{mg} / \mathrm{dl}$ (SD 1.6; range 2.2-8.2 $\mathrm{mg} / \mathrm{dl}$ ). The mean level of circulating iPTH was $1107 \mathrm{pg} / \mathrm{ml}$ (SD 512; range $330-1161 \mathrm{pg} / \mathrm{ml}$ ), assayed by specific radioimmunoassay. Clinical and biochemical data of individual patients are summarized in Table 1.

Thyroid scintigraphy was normal in all patients. Early phase ${ }^{99 \mathrm{~m}}$ Tc MIBI scintigraphy showed normal thyroid uptake in all cases associated with focal extra-thyroid hot spots in the anatomical sites of parathyroid glands region in scintigraphy positive cases. In the delayed phase, ${ }^{99 \mathrm{~m}} \mathrm{Tc}$ MIBI uptake in the thyroid decreased while its relative focal concentration increased in the parathyroid tissue. Two examples of ${ }^{99 m}$ Tc MIBI positive parathyroid scans are shown in Figure 1.
Overall, ${ }^{99 m}$ Tc MIBI scan detected 23 positive sites of focal trace uptake in the 17 patients with positive findings. Among the six patients who had iPTH level $<800 \mathrm{pg} / \mathrm{ml}$, only one patient had positive scintigraphy findings (16.7\%). Among the 17 patients who had iPTH level $\geq 800 \mathrm{pg} / \mathrm{ml}, 16$ patients had positive scintigraphy findings $(94.1 \%)$.

Patients with positive ${ }^{99 \mathrm{~m}} \mathrm{Tc}$ MIBI scintigraphy scans had higher mean iPTH concentrations $(1319 \pm 400$ versus $507 \pm 233 \mathrm{pg} / \mathrm{ml}, \mathrm{P}<0.0001)$, higher mean serum calcium concentration $(9.2 \pm 0.9$ versus $8.2 \pm 0.6 \mathrm{mg} / \mathrm{dl}$; $\mathrm{P}=0.01)$, and longer mean dialysis duration $(111 \pm 24$ versus $52 \pm 35$ months; $\mathrm{P}<0.0001)$ compared to those with negative scans. Age and serum phosphorus level were not significantly different between the two groups.

Thirteen patients with positive ${ }^{99 \mathrm{~m}} \mathrm{Tc}$ MIBI scintigraphy findings had partial parathyroidectomy, removing in total 19 glands with focal trace intake, while four patients declined surgery. On histological examination of these glands, 12 glands showed diffuse hyperplasia (increased number of parenchymal cells with normal lobular structures), four glands showed nodular hyperplasia (at least one well circumscribed, encapsulated and virtually fat cell-free accumulation of parenchymal cells) and three glands revealed parathyroid adenoma. ${ }^{99 \mathrm{~m}} \mathrm{Tc}$ 
MIBI scintigraphy correctly identified the three glands with parathyroid adenoma prior to surgery. In addition, glands found to have nodular hyperplasia had higher trace uptake during scintigraphy and were associated with higher iPTH levels $(>1000 \mathrm{pg} / \mathrm{ml})$ than glands with diffuse hyperplasia. The long-term outcomes of patient who underwent partial parathyroidectomy and those who declined surgery are now being monitored.

\section{Discussion}

Significant morbidity and mortality can result from SHP in patients with ESRD [9]. The Kidney Disease Outcomes Quality Initiative (K/DOQI) Guidelines define parathyroid over-activity in ESRD patients by an iPTH level $>300 \mathrm{pg} / \mathrm{ml}$. The same guidelines recommend parathyroidectomy for patients with persistent levels of $\mathrm{iPTH}>800 \mathrm{pg} / \mathrm{ml}$, associated with hypercalcemia and/or hyperphosphatemia that are refractory to medical therapy [10].

Abnormal parathyroid glands can be located using various techniques in patients with SHP. ${ }^{99 \mathrm{~m}} \mathrm{Tc}$ MIBI scintigraphy has higher sensitivity and specifity than ultrasound in case of SHP [6]. Slower MIBI washout has been observed in hyperactive parathyroid glands compared with normal thyroids and parathyroids [11]. Piga et al stated that ${ }^{99 \mathrm{~m}} \mathrm{Tc}$ MIBI scans do not simply reveal parathyroid enlargement but rather identify hyperfunctioning parathyroid glands in uremic patients with SHP [12]. In the present study, ${ }^{99 \mathrm{~m}}$ Tc MIBI detected hyper-functioning glands in 17 out of 23 HD patients with SHP (73.9\%). Custodio et al demonstrated that $88.8 \%$ of their 18 patients with SHP had hyperactive glands on ${ }^{99 \mathrm{~m}} \mathrm{Tc}$ MIBI scan [13]. An important factor that may influence the rate of positive scintigraphy findings in patients with SHP and parathyroid adenoma is the variable expression of metabolism transporters, such as p-glycoprotein (P-GP) or multidrug resistanceassociated protein (MRP) in the parathyroid glands, which may function as a drug transporter for ${ }^{99 \mathrm{~m}} \mathrm{Tc}$ MIBI $[14,15]$. In our opinion, SPECT technique may increase the sensitivity of ${ }^{99 \mathrm{~m}} \mathrm{Tc}$ MIBI scan in detecting hyper-functioning parathyroid glands compared to planar images.

In the current study, we observed that patients with positive ${ }^{99 m}$ Tc MIBI scans had higher iPTH concentrations and longer duration on dialysis compared to patients with negative scans. This concurs with the findings of previous reports $[12,13,16]$. The association between high trace uptake and nodular hyperplasia on histological examination in this study was expected. It is well known that glands with nodular growth patterns are heavier and show higher proliferative activity than diffusely hyperplastic glands $[17,18]$. Torregrosa et al demonstrated that
${ }^{99 \mathrm{~m}} \mathrm{Tc}$ MIBI scintigraphy accurately reflects the functional status of the hyper-plastic parathyroid glands, with higher uptake grades correlating with the active growth phase [19].

According to the K/DOQI guidelines, effective surgical therapy of severe hyperparathyroidism can be accomplished by subtotal parathyroidectomy or total parathyroidectomy with parathyroid tissue autotransplantation [10]. We referred patients with positive scintigraphy findings for partial parathyroidectomy, removing only glands identified to have active foci of trace uptake. The long-term outcomes of these patients are now being monitored.

\section{Conclusion}

In addition to biochemical data, ${ }^{99 \mathrm{~m}} \mathrm{Tc}$ MIBI parathyroid scan can be a useful screening method to assess the functional status of parathyroid glands in uremic patients with secondary hyperparathyroidism as well as to detect functional autonomy (tertiary hyperparathyroidism).

\section{References}

1. Goodman WG. Recent developments in the management of secondary hyperparathyroidism. Kidney Int. 2001 Mar;59(3):1187-201.

2. Hory B, Drueke TB. The parathyroid-bone axis in uremia: new insights into old questions. Curr Opin Nephrol Hypertens. 1997 Jan;6(1):40-8.

3. Drueke TB. The pathogenesis of parathyroid gland hyperplasia in chronic renal failure. Kidney Int. 1995 Jul;48(1):259-72.

4. O'Doherty MJ, Kettle AG, Wells P. Collins RE, Coakley AJ. Parathyroid imaging with technetium-99msestamibi: preoperative localization and tissue uptake studies. J Nucl Med. 1992 Mar;33(3):313-8.

5. Fukagawa M, Kitaoka M, Inazawa T, Kurokawa K. Imaging of the parathyroid in chronic renal failure: diagnostic and therapeutic aspects. Curr Opin Nephrol Hypertens. 1997 Jul;6(4):349-55.

6. Olaizola I, Zingraff J, Heuguerot C, Fajardo L, Léger A, Lopez J, Acuña G, Petraglia A, Alvarez A, Caorsi H, Drüeke T, Ambrosoni P. [(99m) Tc]-sestamibi parathyroid scintigraphy in chronic haemodialysis patients: static and dynamic explorations. Nephrol Dial Transplant. 2000 Aug;15(8):1201-6.

7. Piwnica-Worms D, Holman BL. Noncardiac applications of hexakis (alkylisonitrile) technetium-99m complexes. J Nucl Med. 1990 Jul;31(7):1166-7. 
8. Taillefer R, Boucher Y. Potvin C, Lambert R. Detection and localization of parathyroid adenomas in patients with hyperparathyroidism using a single radionuclide imaging procedure with technetium-99m-sestamibi (double-phase study). J Nucl Med. 1992 Oct;33(10):1801-7.

9. Slatopolsky E. The role of calcium, phosphorus and vitamin D metabolism in the development of secondary hyperparathyroidism. Nephrol Dial Transplant. 1998;13 Suppl 3:3-8.

10. National Kidney Foundation. K/DOQI clinical practice guidelines for bone metabolism and disease in chronic kidney disease. Am J Kidney Dis. 2003 Oct;42(4 Suppl 3):S1-201.

11. Torregrosa JV, Palomar MR, Pons F, Sabater L, Gilabert R, Llovera J, Fernandez-Cruz L. Has doublephase MIBI scintigraphy usefulness in the diagnosis of hyperparathyroidism? Nephrol Dial Transplant. 1998;13 Suppl 3:37-40.

12. Piga M, Bolasco P, Satta L, Altieri P, Loi G, Nicolosi A, Tarquini A, Mariotti S. Double phase parathyroid technetium-99m MIBI scintigraphy to identify functional autonomy in secondary hyperparathyroidism. J Nucl Med. 1996 Apr;37(4):565-9.

13. Custodio MR, Montenegro F, Costa AF, dos Reis LM, Buchpiguel CA, Oliveira SG, Noronha IL, Moyses RM, Jorgetti V. MIBI scintigraphy, indicators of cell proliferation and histology of parathyroid glands in uraemic patients. Nephrol Dial Transplant. 2005 Sep;20(9):1898-903.

14. Sun SS, Shiau YC, Lin CC, Kao A, Lee CC. Correlation between P-glycoprotein (P-gp) expression in parathyroid and Tc-99m MIBI parathyroid image findings. Nucl Med Biol. 2001 Nov;28(8):929-33.

15. Yamaguchi S, Yachiku S, Hashimoto H, Kaneko S, Nishihara M, Niibori D, Shuke N, Aburano T. Relation between technetium 99m-methoxyisobutylisonitrile accumulation and multidrug resistance protein in the parathyroid glands. World J Surg. 2002 Jan;26(1):29-34.

16. Hung GU, Wang SJ, Lin WY. Tc-99m MIBI parathyroid scintigraphy and intact parathyroid hormone levels in hyperparathyroidism. Clin Nucl Med. 2003 Mar;28(3):180-5.

17. Drueke TB. The pathogenesis of parathyroid gland hyperplasia in chronic renal failure. Kidney Int. 1995 Jul;48(1):259-72.

18. Parfitt AM. The hyperparathyroidism of chronic renal failure: A disorder of growth. Kidney Int. 1997 Jul;52(1):3-9.

19. Torregrosa JV, Fernández-CruzL, Canalejo A, Vidal S, Astudillo E, Almaden Y, Torregrosa JV, Pons F, Rodriguez M. (99m)Tc-sestamibi scintigraphy and cell cycle in parathyroid glands of secondary hyperparathyroidism. World J Surg. 2000 Nov;24(11):1386-90. 